А.А. Арзамазов

Ижевск

\title{
ИЗВЕСТНЫЙ И НЕИЗВЕСТНЫЙ НЕНЕЦКИЙ ПОЭТ ЮРИЙ ВЭЛЛА: ЭТНОХУДОЖЕСТВЕННЫЕ НАРРАТИВЫ
}

Цитирование: Арзамазов А.А. Известный и неизвестный ненецкий поэт Юрий Вэлла: этнохудожественные нарративы // Наследие. 2020, № 2(17). - С.146-167.

DOI: https://doi.org/10.31119/hrtg.2020.2.10

Citation: Arzamazov A.A. Izvestnyj $i$ neizvestnyj neneckij poet YUrij Vella: etnohudozhestvennye narrativy [Known and unknown nenets poet Yuri Vella: ethnoartistic narratives] // Nasledie [Heritage]. 2020, No. 2 (17). - pp.146-167.

DOI: https://doi.org/10.31119/hrtg.2020.2.10

В статье рассматриваются художественные особенности поэтического мира ненеикого поэта Юрия Вэлль. В фокус прочтения попадают его русскоязычные стихотворения, в которых ярко и многообразно представлены экологическая проблематика, любовно-экзистенциальные сюжеты, на разных уровнях поэтики реализован этнокультурный компонент.

Ключевые слова: национальная литература, поэзия, художественный мир, билингвизм, образная система.

Arzamazov A.A. Known and unknown nenets poet Yuri Vella: ethno-artistic narratives The article deals with the artistic features of the poetic world of the Nenets poet Yuri Vialla. His Russian-language poems are in the focus of the reading, in which environmental issues and love-existential plots are vividly and variously presented. The ethnocultural component is implemented at different levels of poetics.

Key words: national literature, poetry, literary-artistic world, bilingualism, figurative system.

Юрий Кылевич Вэлла (Айваседа) (1948-2013) - один из наиболее интересных и при этом недостаточно оцененных национальных поэтов конца XX - начала XXI в. Перелистывая библиографический справочник, изданный к 65-летию Ю. Вэллы, спотыкаешься о мысль, что ценность его текстов лучше поняли, почувствовали на Западе, чем в России. Еще при жизни писателя его переводили на английский, французский, венгерский, финский, эстонский, другие языки, в 1990-е гг. он стал лауреатом премии фонда Сороса. В Эстонии создали сайт, посвященный творчеству Вэллы. Следует заметить, что в последние годы постепенно меняются масштабы прочтения его произведений. И вместе с тем стихотворения, прозаические эксперименты ненецкого писателя все еще остаются на окраинах читательского/критического внимания.

(C) Арзамазов A.A., 2020 
Юрию Вэлле, как и другим писателям из народов России, приходилось заниматься многим, осваивать разные профессии. Он придерживался традиционного северного образа жизни - был охотником, рыбаком, звероводом, оленеводом. В конце 1980-х гг. вынужден был пойти в политику - так хотя бы в какой-то мере можно было отстаивать права коренного населения, усмирять аппетиты нефтяных компаний. Вэлла был глубоким исследователем материальной и духовной культуры лесных ненцев, без отрыва от окружающей этнографической действительности работал научным сотрудником, создал музей под открытым небом. Наконец, он получил образование в Литературном институте имени А.М. Горького.

Юрий Вэлла - поэт столкновений, больших внутренних конфронтаций. Словесность стала для него, пожалуй, основной формой личностного сопротивления. Речь идет не только о неравном противостоянии нефтедобывающим корпорациям, поглощающим ненецкие и хантыйские просторы. Вэлла пытался бороться с реальностью лингвистической несправедливости, стремился сконструировать «иврит» лесных ненцев. Параллельно пробовал писать по-хантыйски, в итоге окончательно перешел на русский, сумев создать синкретическое художественное пространство диалога трех культур, литератур. Долгое время творчество Ю. Вэллы находилось как бы вне контекста принадлежности к какой-либо национальной традиции. Он словно оказался между народов, языков. Однако со временем все более очевидными и закономерными стали внутренние связи его художественного дискурса именно с ненецкой литературой. Изначальная территориальная, языковая удаленность от ойкумены тундровых ненцев была преодолена самим поэтом, ориентированным на тексты ненецких писателей-классиков (таких как В. Ледков, Л. Ненянг). Ю. Вэлла, будучи этническим ненцем, не мог не ассоциировать свои произведения с ненецкой литературной традицией, пусть и представляющей другую вариацию языка.

Творческое наследие Ю. Вэллы только в последние годы постепенно становится объектом научного рассмотрения. Его тексты исследуются как литературоведами [Арзамазов, 2005; Жулева, 2017; Лагунова, 2003, 2007; Тулуз, 2000], так и этнологами [Новикова, 2018; Сподина, 2001]. Основные книги Вэллы вышли еще при жизни автора (это сборники стихов и прозы [Вэлла, 1991, 1996, 2001, 2007, 2013], научнопопулярные работы [Вэлла, 2010, 2012a, 2012б]). Очевидна необходимость многотиражных новых систематизирующих изданий, отражающих в наиболее полном формате сумму произведений поэта. Остались рукописи, неопубликованные материалы, также претендующие на отдельное издание. На сегодняшний день отсутствуют монографические труды, в которых осмысливался бы феномен художественного мира Вэллы.

Своеобразие поэтической системы Юрия Вэллы определяется рядом особенностей, которые мы хотели бы обозначить. Ю. Вэлла предпочитает верлибр, развивает традицию свободных стихов в рамках ненецкой литературной традиции. Однако среди его стихотворений есть и рифмованные, которые, как правило, жанрово маркированы (например, песни). Стихотворные произведения Ю. Вэллы отличаются достаточно большими текстовыми объемами, тексты-миниатюры встречаются редко. Отчасти это специфическое явление обусловлено ярко выраженной сюжетностью стихов: в них развернуто представлены жизненные ситуации, истории переживания, картины ненецкого мироустройства, описываются глобальные изменения экологи- 
ческой миросистемы ненцев. Для творчества Ю. Вэллы характерна выверенность, продуманность художественного пространства, его книги четко структурированы, в поэтических сборниках явственно прослеживается проблемно-тематическая классификация текстов, большинство стихотворений озаглавлены. Поэтической модели Вэллы свойственна высокая степень циклообразования, чаще встречается форма триптиха. Многие стихотворения Ю. Вэллы имеют эпиграфы, преимущественно это отрывки из бесед представителей ненцев или ненецкие пословицы, предваряющие лирический сюжет наблюдений.

Поэзия Юрия Вэллы в значительной степени автобиографична. Автор творчески откликается на события, которые происходят непосредственно с ним, с его ближним кругом (семья - род - народ). Границы его художественного мира, как правило, совпадают с пространством малой родины, с континуумом личного опыта.

Книги Юрия Вэллы (речь идет о художественных изданиях) лишь с оговорками можно назвать стихотворными сборниками. Поэтические тексты дополняются прозаическими вставками, ненецкий писатель обращается к разным образно-жанровым форматам. Фрагменты прозаического письма (короткие истории) тематически, сюжетно корреспондируют с поэтическим блоком. Стихотворные сборники Юрия Вэллы, выходившие в 1990-е - 2000-е гг, имеют общий текстовой «каркас». Автор добавляет к ранее изданным стихам несколько новых, при этом расширяет языковое пространство каждой новой книги, включая в них переводы на другие языки (например, на французский). Поэт каждый раз меняет структуру издания, собирает прежде разрозненные стихи в циклы, тем самым создавая новый художественный контекст их бытования.

Стихи, написанные по-ненецки, содержательно, эмоционально несколько отличаются от русскоязычных текстов. Это тексты особой образной «прозрачности», созерцательности, они наивны, прямолинейны, напоминают детские стихи, восходят к фольклорным образцам. Иногда поэт создает своеобразные ненецкие хокку:

\section{Нисы малхат}

Капити` хала' куутин товон`...

Ка' мамата нӓпта?

$$
\text { [Вэлла, 2001, с.7] }
$$

\section{Ранним утром}

По двору скачет сорока...

Ну и что ж?

$$
\text { [Вэлла, 2001, с.6] }
$$

Отдельной ремарки заслуживает качество русского языка стихов Юрия Вэллы. В его текстах нет стилистического напряжения неродного слова, выраженных грамматических неправильностей, синтаксического «коллапса». Его русский, слегка «разбавленный» терминами ненецкой духовной и материальной культуры, кажется абсолютно естественной формой творческого самовыражения. Вэлла гармонично представляет по-русски свой сложный, символически и ситуативно насыщенный ненецкий мир. В целом выбор русского языка/переход на русский язык в системе литератур народов России - все более распространенное явление, возможно, требующее пересмотра и расширения смысловых границ категории «национальная лите- 
ратура». Ю. Вэлле, перешедшему на русский, удалось избежать «языковой ломки», преследующей многих писателей-этнофоров, рискнувших творить по-русски.

Главная тема творчества Юрия Вэллы - тема случившейся экологической катастрофы. Северные территории Западной Сибири, места исконного проживания лесных ненцев, хантов и манси, на протяжении десятилетий осваиваются нефтедобытчиками. Вырубались леса, истреблялись животные, природе был нанесен невосполнимый ущерб. Прежде обширные природно-культурные пространства сузились до островков хрупкой стабильности. Привычный уклад жизни коренных народов оказался под угрозой, обострились социальные проблемы, ассимиляция приобрела огромные масштабы, процесс утраты миноритарных языков региона, кажется, уже невозможно остановить. Юрий Вэлла, многие другие национальные писатели Югры (например, хантыйский прозаик Еремей Айпин) восприняли происходящее как личный апокалипсис, уничтожающий столетиями складывавшуюся систему духовных ценностей, хозяйственных навыков. Примечательно, что экологическая тематика в произведениях большинства ненецких писателей отсутствует или обозначена факультативно. В случае с Ю. Вэллой один из факторов радикализации этноэкологической проблематики - месторасположение его стойбища, земель его рода. Окрестности Нижневартовска, Сургута, Ханты-Мансийска пострадали особенно сильно. Здесь регулярно случались техногенные аварии, которые обычно замалчивались, скрывались от общественности. Поэтическое освещение, осмысление катаклизмов Вэллой в некотором роде нужно прочитывать как опыт коллективного духовного сопротивления, как попытку создания особого дискурса этнической травмированности.

Одно из наиболее ярких, пронзительных, глубоко пессимистичных стихотворений ненецкого поэта - «Мутация». Текст открывается фрагментом разговора деда и внука, в котором сообщается о жутковатом улове (в родном озере поймали щуку с четырьмя ноздрями, рогами). Автор не ограничивается описанием, придумыванием внешних мутаций (предъявляет читателю образ своего мутированного деда), он предполагает наличие мутаций внутренних, ментально-экзистенциальных, деформирующих сознание и поведение человека. Вэлла почти всегда придает своим финальным строкам выраженное философское звучание:

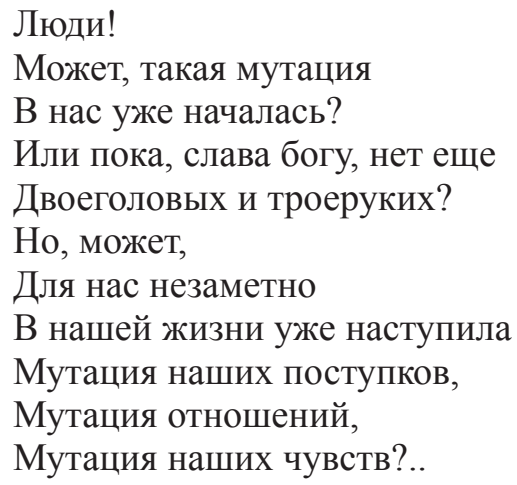

[Вэлла, 2001, с.135]

Ю. Вэлла часто выдумывает колоритных персонажей, говорит от их имени, подбирает оригинальную жанровую конструкцию. Такая стратегия текстопорождения 
явлена в произведении «Причитания Старого Усти». Это причитания человека, не мыслящего себя вне своего этнокультурного ландшафта, природного универсума. Сталкиваясь с ужасающей реальностью современной промышленной цивилизации, герой испытывает постоянную физическую и душевную боль. Его тело и тяжело раненная индустриальными вторжениями природа родного края образуют единый живой организм. Внутренние терзания, сопротивление Усти, мучительное ощущение текущей ситуации получают языковое выражение в виде частицы «не»: уже невозможно что-либо изменить и невозможно принять происходящее. На наш взгляд, неслучайна внутритекстовая актуализация «инфинитивного ресурса»: не уснуть, не проснуться, некуда деться, некогда оглянуться, некогда задуматься. Инфинитивное письмо в структуре текстового целого нередко указывает на особый риторический статус, свидетельствует о высоком уровне экспрессивности высказывания. Уничтожение экосистемы для лирического «Я» равноценно самоуничтожению. Поэт в рассматриваемом стихотворении оперирует категорией «род», которая в его творчестве являет собой многогранную смысловую синкрету. Род у Ю. Вэллы - особое этническое, природное, духовно-ценностное измерение. Тундра, тайга, ягель, деревья выступают как своего рода образные заместители ушедших из жизни бабушки, дедушки. Одним из говорящих рефренов текста становится глагольная форма стонет, несущая открытый психосемантический посыл. В художественной ткани стихотворения задействованы цветовые символы, также характеризующие реальность этноса, бытие этнофора:

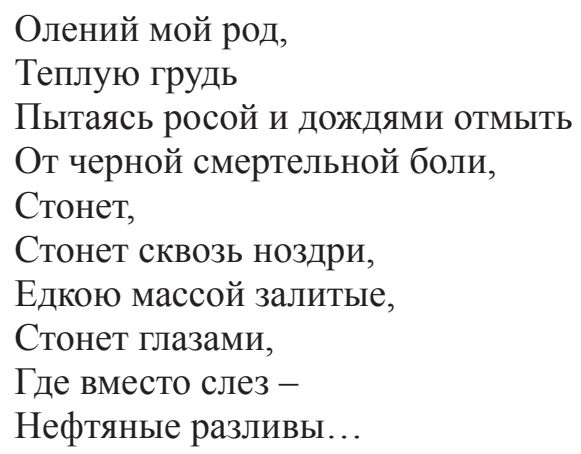

[Вэлла, 2001, с.149]

«Экологические» стихотворения в творчестве Ю. Вэллы особенно объемны. Повидимому, поэт хочет многое в них вместить, показать, привести разные художественные аргументы. В основе этих текстов - повторение определенных мотивов, образов, ситуаций. Одна из заметных поэтологических деталей лирики ненецкого автора - обилие вопросительных знаков, вопросительных контекстов. Лирический субъект постоянно находится в режиме вопросительности. Произведение «Отнята земля - отнята душа» начинается и заканчивается вопросами, ответы на которые очевидны и сложны одновременно:

Где тропа,

По которой кочевал мой род?

Где урочище, что зверьем их кормило? 
Где река,

Из которой поили детей?

Что с их небом,

Которому не только молились?..

$$
\text { [Вэлла, 1991, с.7] }
$$

В стихотворении постулируется мотив потери древнего ненецкого мира, своих корней, обыкновений. Этот мир ушел вместе с поколением бабушек/дедушек, его уже не вернуть, не возродить. Моделируется картина того, как было раньше, приводятся принятые в системе этноса модели, нормы повседневного отношения к природе, которые перестали работать, соблюдаться. В произведении фигурируют колористические эпитеты (бельй месяц, белое солнще), символизирующие сакральный статус небесных светил.

Очередной пессимистический текст, продолжающий ключевую тему творчества Юрия Вэллы, пронизан скепсисом по отношению к вере, религиозно-мифологическим представлениям. Лирический герой призывает имплицированного собеседника молиться своим древним богам, осознавая бесперспективность таких ритуальных прошений. Ненецкие боги умерли, и все же нужно следовать традициям предков, просить у богов помощи, невзирая на их молчание:

\section{Но боги молчат. \\ Они разуты, \\ Разграблены, Из ружей расстреляны...}

$$
\text { [Вэлла, 1991, с.9] }
$$

В стихотворении история и реальность народов Югры воспринимаются сквозь призму репрессий, социального неблагополучия (алкоголизм, бедность), ассимиляции, утраты своих территорий.

Взаимосвязи природы и человека в представлении Ю. Вэллы глубинны. Их разрыв всегда чрезвычайно болезненный, несправедливый. В произведении «Заброшенный лабаз» обыгрывается мотив одиночества природы, которая остро переживает длительное отсутствие общения с людьми:

Тропинка заросла.

Уже лет двадцать

Хозяин на упряжке не был здесь.

Забыл свой лабаз?

Сам сгинул?

Или покинул родину свою?

Молчит сурово бор,

Заросший сосняком...

Молчит ручей соседний

С просохшим дном...

[Вэлла, 1991, с.13]

В данном случае речь идет и о «разлуке» природы и этноса. 
В стихах Ю. Вэллы хорошо выписан образ врага. Поэт редко изображает в этой ипостаси людей. На первый план он выводит машины:

Здесь росла береза...

Бульдозер вырвал ее с корнями

И гусеницами стальными в липкую грязь вмолол...

[Вэлла, 1991, с.12]

Отнята земля

И брошена на растерзание

Под стальные гусеницы твои.

А проголодавшийся экскаватор,

Лязгая неистово,

Уже вынимает внутренности...

[Вэлла, 1991, с.7]

Враги, вредители - это и «размытое» множественное число, отсутствие какойлибо персонификации:

O, тайга! -

Нет тайги - ее вырубили,

О, родная земля! -

Не осталось земли -

Ее превратили в сплошные дороги,

Ее превратили в сплошные карьеры,

Ее превратили в сплошные окраины городов.

[Вэлла, 1991, с.31]

Особое место в поэтическом отображении природной катастрофы Югры занимает образ нефти. Нефть становится своеобразной «мертвой водой», она замещает собой живую воду сибирских рек:

Не выпита река,

А залита нефтью,

Не осушена река,

А заканчивается по притоку в час

Каждый день

Вот уже сотню месяцев

В нефтяные пласты...

[Вэлла, 1991, с.8]

По Ватьёгану плывет

Нефть,

Нефть,

Нефть.

Лодку, сети и весло

Пропитала нефть.

Щуку вспорешь -

Нож в нефти.

[Вэлла, 2001, с.133] 
Среди основных человеческих персонажей поэзии Ю. Вэллы - дедушки и бабушки, к которым также относятся люди старшего поколения. Они носители традиционной культуры, хранители рода, для них существует только один ненецкий мир с его еще не разоренной природой, живым, богатым языком. Дедушки и бабушки - постоянные герои экологических стихотворений. Это и реальные люди, столкнувшиеся с неразрешаемыми проблемами глобального индустриального наступления, и одновременно - добрые духи, посылающие сигналы тревоги своим потомкам.

Яркий пример стихотворений данного типа - «Песня бабушки Ненги». Песня один из ключевых жанров не только ненецкого, хантыйского фольклора, но и поэтической системы Ю. Вэллы. Бабушка Ненги шьет обувь и поет песню, в которой как бы проступают сюжеты будущего, предвидятся события жизни повзрослевшего внука. В тексте реализована заклинательная функция, в качестве этнического маркера используется ненецкое междометие:

Вот сошью кисы я внуку.

Нгадьеей-нго!

Чтоб не мерз в мороз и вьюгу.

Нгадьеей-нго!

А когда пойдет за зверем

Далеко,

Чтобы лыжи не скрипели.

Нгадьеей-нго!

Будет он пасти оленей.

Нгадьеей-нго!

Из реки добудет нельму.

Нгадьеей-нго!

[Вэлла, 2001, с.27]

На примере рассматриваемых персонажей можно выявить и отдельные этногендерные особенности, характерные для ненецкого общества. В поэтическом мире Ю. Вэллы женщины открыты, коммуникабельны, стараются уйти от больших «мужских» проблем в «малые» женские дела. Мужчины, напротив, закрыты, малообщительны, погружены в себя. Их волнуют глобальные вопросы сегодняшнего дня, угнетает, травмирует ощущение собственной беспомощности.

С большой нежностью, художественной достоверностью создан образ старой ненки Ымчи. Она беспокоится о сыне, находящемся в других широтах, далеких краях, искренне не понимает, для чего людям нужно покидать отчий дом, жить по другим правилам, принимать обыкновения чужих. Одна из деталей лирического портрета - ненецкие звуковые рефрены:

Маленький мой,

Разве для тебя

Нет улова в родной реке?

Маленький мой,

Разве в нашем стаде

Нет олененка для твоего тынзяна? 
Маленький мой, Отчего ты сегодня не со мной?

Ёх-хо-хо-хов!

Что-то тревожно твое письмо.

Ёх-хо-хо-хов!..

[Вэлла, 2001, с.33]

В тексте «Политический разговор» [Вэлла, 1991, с.10-11] дед и внук обсуждают новые слова, звучащие по радио («перестройка», «инфляция», «демократизация», «межнациональные отношения»). Эти понятия для носителя традиционного ненецкого мировоззрения не просто лишены смысла, не вписываются в «ментальный универсум», они представляют мир ложных ценностей, «мир, перевернутый наизнанку». У стихотворных героев Юрия Вэллы очень сложные отношения с современностью.

Дед в стихотворениях Вэллы воспитывает внуков, бабушка занимается внучками. Примечательно, что у ненецкого поэта за редким исключением «пропущены» персонажи родителей.

Образ задумчивого, ушедшего в себя деда явлен в произведении «У телевизора». Он внезапно «отключается» от мира своей семьи, увлеченной новым телевизором, предчувствует большую беду. Для него вдруг перестали иметь значение внешние радости:

Сегодня радость в стойбище

Большая -

Мой дядя в чуме телевизор

Поселил,

Трещал огонь в печи,

Барахтались перед экраном дети,

А дед сидел в тени

И подбородок теребил...

Но дед не удивлялся.

Он был хмур сегодня.

За спинами сидел в тени

И, сдвинув брови,

Подбородок теребил...

А вечером

Мне по секрету бабушка сказала,

Что вчера

У дороги на буровую

Дед откопал

Две туши обезглавленных оленей,

Полмесяца назад пропавших

В соседнем стойбище.

[Вэлла, 2001, с.147-148]

Приведенный текст являет собой пример сложного устройства многих стихов Ю. Вэллы. Наблюдаются текстуальные участки с прозрачным стремлением автора к рифмовке, которые как бы «обрываются» возвращением к верлибру. 
Ключевой символ художественного мира Юрия Вэллы - образ неба. Ему приписываются антропоморфные свойства. Оно взаимодействует с лирическим героем, отвечает на его реплики, чувствует настроение, отвечает на эмоциональные порывы. Очень часто лексема «небо» употребляется с притяжательным местоимением «мой», подчеркивается особая метафизическая сопряженность неба и человека. «Свое» небо - это прежде всего небо малой родины:

Говорю тебе: «Здравствуй!»

И небо мое

Следом за мной

Тысячу раз повторяет:

«Здравствуй!..»

Хочется крикнуть: «Люблю!»

И небо мое ждет,

Чтоб следом за мной

Тысячу раз повторить этот возглас...

[Вэлла, 1991, с.23]

Небо в стихах Вэллы может быть и чужим, безучастным, отстраненным, неожиданно равнодушным по отношению к происходящим в жизни событиям. Так, оно не реагирует на умерщвление неродившегося ребенка. Лирический субъект, напротив, ждет отклика - сопереживания, осуждения:

На небе ни облачка!

На небе ни одной звезды!..

Сегодня по блату убит мой сын.

Без всякой записи -

По знакомству...

Не на войне пулеметной очередью,

А на гинекологическом кресле...

[Вэлла, 1991, с.25]

Небо ревностно относится к перемещениям героя, опасается его существенных внутренних изменений после встречи с чужими землями:

И вот

Я снова возвращаюсь

С пляжного лета

На тундровый простор.

Как долго здесь я не был!

В глаза мои со всех сторон

Испытующе глядит

Доверчивое небо.

И чувствую,

Оно меня спросить желает:

- Не стал ли и ты

Серым 
Средь серых людей?

Вернулся ли прежним -

Белым?..

$$
\text { [Вэлла, 1991, с.39] }
$$

Поэтом вновь востребованы цветовые концепты. В его представлении люди делятся на серых и белых, испорченных цивилизацией и чистых, искренних, защищенных своим народом и природой.

Семантико-эстетическая значимость образа небо особенно заметна в цикле «Весенний триптих». В первом тексте триптиха приводится перечень эпитетов, характеризующих разные состояния неба, - как внешние, визуальные, так и внутренние, психоэмоциональные. Небо у Ю. Вэллы всегда живое, оно - важнейшая часть природного космоса - неразрывно связано с пространством родины:

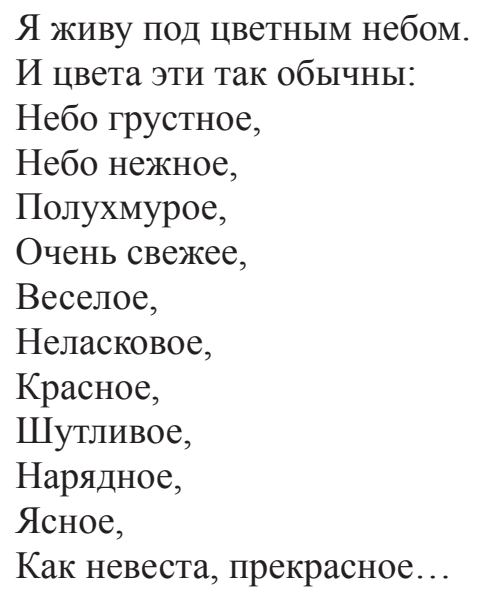

[Вэлла, 2001, с.19]

Среди предложенных эпитетов неба - устойчивые в творчестве Ю. Вэллы колористические определения (желтое, зеленое, синее, фиолетовое, позолоченное, посеребренное), физические характеристики (неподвижное, быстрое, жидкое, густое, мокрое, сухое), антропоморфные качества, этноментальные оттенки (заважничавшее чиновником, по-ненецки простецки близкое). Жизнь неба описывается и с точки зрения потенциальности: «небо может прилечь на поле; отдохнуть после трудной охоты; небо может парить над миром; небо может стать наилегчайшим и бесшумным». В конце стихотворения автор подчеркивает: «мое небо» навсегда останется моим, оно не станет другим, не будет принадлежать другому. Во втором тексте триптиха лирический герой продолжает описание разных ипостасей неба. Происходит расширение сферы зрительного, магистральный образ приобретает живописную выразительность. В последних строках небо контекстуально вписано в философские обобщения, «обставлено» риторическими вопросами:

Только под каким небом Ты будешь жить?

Каким именем Тебя называть?

[Вэлла, 2001, с.21] 
В заключительном третьем стихотворении «Вечное небо» образ неба содержательно соотнесен с циклами человеческой жизни, с ощущением ее быстротечности. В небо смотрят, его чувствуют и новорожденные, и дети, взрослые, влюбленные, умирающие. У каждого из них - своя картина, свое имя неба:

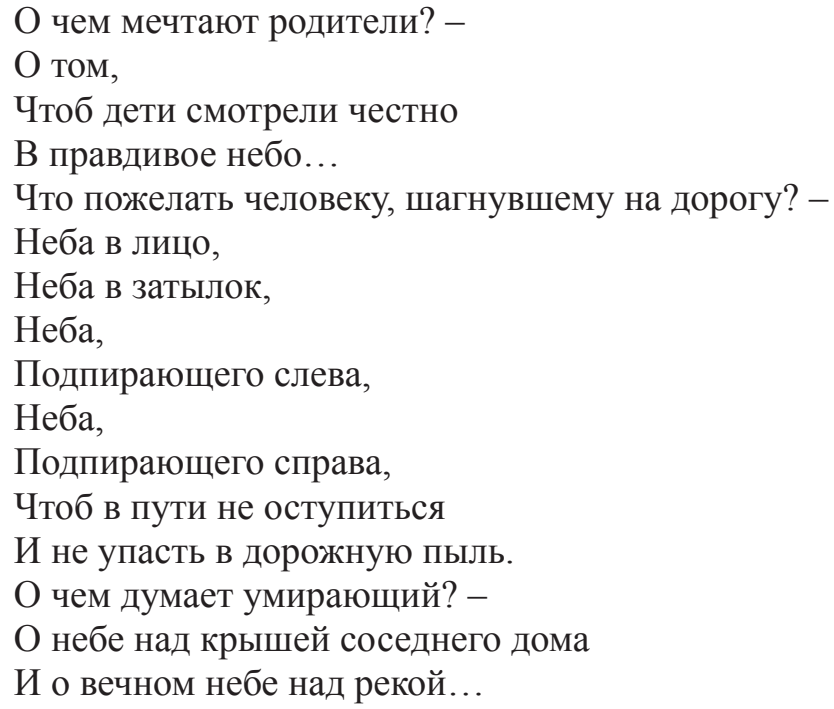

[Вэлла, 2001, с.22]

Продуктивность символа неба в художественной системе Юрия Вэллы объясняется как его изначальной мифологической содержательностью, так и высокой степенью эстетической функциональности.

Наряду с образом неба одним из излюбленных лирических символов Юрия Вэллы является дождь. Это несколько нетипичный выбор для ненецкого поэта: главным атмосферно-символическим явлением северного художественного ландшафта обычно становится снег. Однако Вэлла изменяет этой традиции, по-видимому, не столько в силу несколько иного географического положения своей малой родины (южные границы ненецких этнических территорий), сколько по причине лирикосемантической многоплановости дождя. В некотором роде, актуализируя изобразительные коды и психологические подтексты этого символа, поэт вступает в диалог с традициями «большой» словесности.

Осенний дождь в одноименном стихотворении [Вэлла, 2001, с.14] оказывается объектом созерцания. Лирический герой наблюдает за ним, описывает, как дождь меняет картинку за окном. Размываются границы внешнего мира, но при этом визуально обостряются отдельные составляющие панорамы. В тексте дождь сравнивается с юрким червем, проникшим глубоко в землю. Он активен, ему хочется попасть в человеческое пространство, он ассоциируется с ненецким шаманом.

Дождь у Ю. Вэллы манифестируется и как символ очищения, удачи:

Сегодня утром дождь

Дорогу мне переступил.

Когда-то дед мне говорил, 
Что дождь такой

Несет удачу.

Я по селу иду,

Лицо свое не пряча,

И чистою водой

Дождь заполняет

Следы мои...

[Вэлла, 2001, с.15]

Так же, как человек и дождь, взаимосвязаны человек и снег. В поэтическом отражении Вэллы цвет первого снега и утомленного жизнью человека разный. Снег, природа очищают людей от серости повседневности:

Выпал первый снег -
Белый, белый, белый.
Вышел человек -
Серый, серый, серый...
В воздухе парят
Легкие снежинки.
Тают на лице,
Падают на плечи.
Словно вот такой
Радуются встрече.
И стоит уже,
Белый, белый, белый,
Тот же человек,
Что был серый, серый...

[Вэлла, 2001, с.65]

В стихотворном корпусе Юрия Вэллы заметное место занимают урбанистические нарративы. Любопытно, что поэт отказывается от изображения городов, которые находятся рядом с его родовыми землями. Основное городское пространство у Вэллы образуют московские топосы. Художественное упоминание столицы, повидимому, имеет автобиографические корни (поэт учился в Литературном институте им. Горького). И вместе с тем Москва для Ю. Вэллы абсолютно чужая. Здесь люди живут другими заботами, преследуют другие цели. К урбанистическим стихам относится текст «На троллейбусной остановке». Лирический субъект, просматривая объявления, испытывает чувство недоумения, внутреннее несогласие. Картина мира, потребности и ценности москвичей кажутся субъекту-этнофору ненастоящими, лишенными подлинного смысла:

Стою возле будки

На остановке,

Читаю обрывки бумажных фраз:

«Меняется...»,

«Срочно меняем...»,

«Разъезд...», 
«...трехкомнатную,

С балконом на юг.

К концу пятилетки...

И подумалось вдруг:

Неужели когда-то

На развилке оленьих дорог

И мои сородичи

Станут взывать:

«Семья развалилась,

Меняется чум...»,

«Мой муж алкоголик,

Меняю семью...»,

«Поссорились с зятем,

Меняется род...».

[Вэлла, 2001, с.66-67]

Отраженная в приведенных строках советская действительность уже «предсказывает» скорые разъезды, переезды, глобальные изменения, исчезновения.

Город у Вэллы «рифмуется» с одиночеством, ассоциируется с молчанием. Он угнетает, давит, лирическому герою здесь неуютно, холодно:

Самолет улетел.

Я остался один

В незнакомом мне городе...

Я остался один

В незнакомом мне мире,

Где не с кем поговорить...

И со всех сторон

Сдавливает меня

Немой город,

В котором некому сказать слово;

Каменный город,

В котором некого любить;

Какой сегодня ужасно холодный день!

[Вэлла, 1991, с.27]

Урбанистические характерологические эпитеты повторяются в произведении «Дом». Дом, олицетворяющий собой городское пространство, называется скупым, холодным, слепым:

Весь дом стоит скупой,

Холодный

И слепой...

[Вэлла, 1991, с.29]

Дом - и реальный топос, и мираж прошлого. Это место пробуждает любовные воспоминания, переносит в прошедшие годы. Очевиден отрицательный контекст восприятия города. 
Москва в стихотворении «Холодный бульвар» [Вэлла, 1991, с.28] - мир иллюзий, место несбывшихся надежд. Как и в предыдущем тексте «Дом», жизнь в городе для «Я»-субъекта полна разочарований, лишений, напрасных ожиданий. То ли реальная, то ли воображаемая возлюбленная проходит мимо героя в переходе на Пушкинской площади, не обращает на него внимания.

Города у Юрия Вэллы подразделяются на настоящие и ненастоящие, временные. Об урбанистическом топосе второго типа стихотворение «Временный город». Когалым Лор, построенный для нефтяников, - локус-призрак, воплощающий ложные материальные ценности и духовную ограниченность живущих здесь людей. Хантыйская этимология искусственного города глубоко символична: это мертвое место, земля умерших. Не знающий языков и древних имен человек со стертым этническим обликом возводит жилище там, где нельзя. Любопытно художественное представление коренных народов. Ненцы, ханты с некоторым злорадством наблюдают за обыкновениями приезжих-чужих:

Пышен блеск нефтяных рублей.
Чумы стиснуты поодаль.
Хант смеется в оскал бубна.
Ненец в ресницы ухмыляется -
На мертвом месте
Мертвый город
Мертвым будущим бахваляется.
Временные люди
Во временном баре
Временное пиво
С жадностью отхлебывают.
Временное столетие
Над их плечами
Временные минуты
В часах отстукивает...

[Вэлла, 2001, с.136]

В целом в поэзии Юрия Вэллы город представляет собой визуально неактивированный хронотоп. Лирический субъект делится с реципиентом набором ситуаций, своими внутренними переживаниями, но не зрительными впечатлениями. Урбанистические тексты ненецкого поэта оказываются психологически концентрированными, пессимистическими, отличаются скупой образностью, доминированием внутреннего над внешним. Изображение города в стихотворениях Ю. Вэллы, его негативного художественного представления, описания корреспондирует со стратегиями, сложившимися в других литературах народов России.

В структуре поэтического творчества Ю. Вэллы выделяется группа текстов, которые автор определяет как песни [Вэлла, 1991, с.41-48]. Они композиционно и содержательно взаимосвязаны между собой, этнографически выразительны. В этих текстах сосредоточены отдельные мифологические представления ненцев, которые подвергаются значительной авторской переработке. Художественная семантика данных стихов часто затемнена, в них отражен поток сознания персонажей - во́рона, 
красной белки, хозяйки Агана, хозяйки Казыма. Они живут в своей мифологической действительности, параллельной миру людей. Человек занимает важное место в их размышлениях, монологах. Он превратился в истребителя всего живого, в ненасытного охотника-потребителя, потерявшего чувство меры, дозволенного. Птицы, животные, напротив, наделяются поэтом особой рефлексивностью. Они осознают свою ответственность за природу, они обеспокоены, уязвлены резкими переменами, случившимися с человеком.

Еще один заметный жанровый эксперимент Ю. Вэллы - поэтический диалог с русской югорской поэтессой Татьяной Юргенсон, получивший название «Охота на лебедей» [Вэлла, Юргенсон, 2001]. Это перекличка стихотворений, взаимодействие двух разных стилей, иногда «устремленных» навстречу друг другу. Входящие в данную жанровую модификацию тексты на первый взгляд тематически разноплановые. Вместе с тем Вэлла предлагает творческому собеседнику набор своих инвариантных лирических мотивов, предлагает разделить его мировидение. Соавтор включается в эту игру, пытается настроить оптику ненецкого этнофора. Реплики, реакции лирического «Я» Т. Юргенсон принадлежат человеку города, осторожно, с интересом познающему миры природы. «Охота на лебедей» - развивающаяся цепочка сюжетов и форм: диалог начинается с загадки, продолжается текстами-наблюдениями за жизнью рек, текстами-мечтами о полете, парении, потом происходит переключение на философско-социальную проблематику. При этом именно стихи Юрия Вэллы привычно транслируют состояния значительного эмоционального напряжения, образы опасной современности. Уже невозможно просто так спрятаться в свой мир, укрыться от внешних неблагоприятных, расшатывающих этническое мироздание условий, рамок бытия.

Значительный, художественно значимый пласт поэзии Юрия Вэллы составляет любовная лирика. Любовь в его стихотворениях полна романтизма, самопожертвования, вдохновения, недосказанности, печали. Отношения между мужчиной и женщиной в традиционном ненецком обществе были регламентированы народными предписаниями. Любить человека нужно правильно, оглядываясь на обычаи. При этом глубокое знание «кодекса любви» предков не мешает автору создавать собственную реальность чувства, свою этику.

В тексте «Иду на охоту» [Вэлла, 1991, с.20] символическое определение любви эхо, сопровождающее лирического героя повсюду. Метафорическое эхо Ю. Вэллы явление многогранное, не только акустическое, но и визуальное, воображаемое, эмоциональное, тактильное. Вновь настоящее большого чувства соотнесено с прошлым.

Там, где возникает сильное психологическое напряжение, у Ю. Вэллы начинают говорить, оживать вещи. Предметный код актуализирован в произведении «Опустел мой дом» [Вэлла, 1991, с.26]. Это одно из наиболее проникновенных стихотворений ненецкого поэта. С лирическим героем печаль расставания делят объекты материального мира - крыльцо, стол, стул, дверь, окно. Вещи, дом выступают как свидетели общего, единого прошлого «Я» и «Ты». Символы двери, окна подчеркивают ситуацию пограничья, усиливают ощущение одиночества. В стихотворении «Вроде все» [Вэлла, 1991, с.26] «оживают» дверь и порог, в традиционной культуре символизирующие границу, переход из одного состояния в другое. Данная мифологи- 
ческая функция образов срабатывает, лирический субъект, выделяя указанные пространственно-предметные реалии, предчувствует их сакральное предназначение. Перешагивая через порог, захлопнув дверь, он выходит из отношений.

Любовную лирику Вэллы отличает деликатность. Поэт уклоняется от художественной передачи неудобных подробностей распадающихся отношений. Его привлекают, вдохновляют высокие переживания, послевкусие разлуки. Возлюбленная загадочна, закрыта от читателя.

В любовных стихах Вэллы может просматриваться эротический контекст. В «Купании на рассвете» явлена ситуация тайного созерцания, подглядывания. На обнаженное женское тело претендует река. Она, в отличие от лирического героя, имеет доступ к запретному:

Утром ранним,

Когда туман висел на прибрежных кустах тальника,

Я подсмотрел,

Как ты осторожно входила в студеную воду реки,

Как взлетали, захлебываясь,

Твои плечи и руки,

И тяжелая ревность рождалась во мне

К реке.

Почему это она,

А не я

Робко касаюсь пальцами ямочки на твоем животе?

Почему это она,

А не я

Осторожно прикрываю дрожащей ладонью

Нахально торчащие острые бугорки

На груди?

Почему это она,

А не я

Припадаю пересохшими губами

К впадинке между твоими ключицами?

Почему это она,

А не я,

Не я с жутким страхом вбираю тебя в свои объятия?..

[Вэлла, 1991, с.21].

В творчестве Юрия Вэллы находит отражение одна из наиболее острых социальных, физиологических проблем народов Севера - алкоголизм. Поэт не боится об этом открыто говорить, он предельно откровенен в своих стихах. Приукрашивание этнической действительности - не его художественный сценарий. Об алкоголизме Вэлла может писать как документально, реалистично, так и создавая иносказательный сатирический контекст, прибегая к очевидным сравнениям:

Твой дядя на лебедей тоже охотился.

Некоторые

Круглозадые жены 
Приезжих геологов длиннорублевых

Поили его самогонкой.

И скупали

Невыделанные, кровяные,

Наспех ободранные,

Вылинявшие,

Лебяжьи шкурки...

А потом

Врач-эксперт

Вынес заключение:

«Отравление алкоголем»...

[Вэлла, 2001, с.142]

Прилетел журавль с Севера на Юг.

Сел на кочку.

Скинул крылья,

Выпил водки

И... каюк!

[Вэлла, 1991, с.14]

В последнем стихотворении обозначена еще одна важная для ненецкого поэта тема - тема особенности Севера, его противопоставленности Югу. Юг воспринимается как пространство опасности, где с северянами может случиться все что угодно. Родная северная земля оберегает своих, здесь нет пугающей неизвестности. В целом противостояние Севера и Юга - одна из вариаций бинарной оппозиции Свое/Чужое, регулярно актуализируемой Юрием Вэллой.

Пьянство у Вэллы напрямую связано с социальным давлением, обусловлено деформацией основ этнического миропорядка, разрушением этических норм, сменой мест существования. Так, на стойбище своего или гостя встречали едой. В селе, деревнях вместо еды - алкоголь. При этом особенно заметные негативные изменения произошли с женщиной. Именно она стала главной жертвой переселения со стойбища в поселок, оказалась уязвимой перед искушениями новой-чужой жизни:

На стойбище соседа:

Открою одну дверь -

Женщина протянет кусок рыбы.

Открою вторую дверь -

Женщина протянет кусок мяса.

В третьем доме для меня

Женщина согласится разделить трапезу...

В соседней деревне:

Открою одну дверь -

Женщина протянет кружку пива.

Открою вторую дверь -

Женщина предложит отведать водки. 
В третьем доме для меня

Женщина в день рождения устроит попой...

[Америка Юрия Вэллы]

За несколько лет до смерти Ю. Вэлла побывал в США. Путешествие, одним из организаторов которого был известный российский филолог, переводчик, профессор МГУ А.В. Ващенко, «переросло» в серию стихотворений и путевых заметок. Этот срез художественного наследия Вэллы, как и многие его поздние тексты, полностью не опубликован. Отдельные фрагменты были размещены в Интернете. Поэта интересуют прежде всего бытие и быт американских индейцев, с которыми он ассоциирует ненцев, находит немало общего в их исторической судьбе и повседневности. Центральным образом американских стихов становится река Рио-Гранде. Представленное в тексте «ритуальное общение» лирического героя с рекой восходит к фольклорно-мифологическим представлениям ненецкого этноса, сакрализующим воду, реки. Рио-Гранде для него - одно из воплощений «большой живой воды» человечества, духовной памяти предков. «Я»-субъект, невзирая на огромное расстояние между Америкой и Сибирью, ощущает ментальную близость, родство двух исчезающих народов. Однако эта авторская мысль прочитывается между строк, не эксплицируется. Для Вэллы значительно важнее проявить внутреннее единство со своим этносом, который в лице отдельно взятого этнофора постигает Америку:

Я опустил в реку монетку за себя, за то, что осмелился топтать здешнюю землю, корни растений, за то, что осмелился пить здешнюю воду, вдыхать здешний воздух.

Я опустил в реку монетку за своих товарищей-родственников, которые здесь находятся вместе со мной в Америке, и здесь останутся наши следы, наше влияние.

Я опустил в реку монетку за близких, которые остались дома на Тюйтяхе и в Варьёгане, потому что я все время чувствую, что и они со мной здесь, что мысленно и они вместе со мной топчут здешнюю траву, опускают руки в воду здешней реки и вдыхают высокогорный воздух здешней земли.

Я чувствую себя проводником между разными континентами.

Я чувствую себя проводником между полюсами нашей Планеты.

Я гляжу на здешнее солнце, но чувствую тепло солнца моей тундры. Я моюсь прохладой здешней реки Рио-Гранде, но чувствую в этот миг прохладу

Тюйтяхи и Оби.

Спасибо вам, Боги, за то, что я есть, за то, что я чувствую окружающий мир, за то, что я способен еще любить Жизнь! [Америка Юрия Вэллы]

Юрий Вэлла в США встречался с индейскими поэтами, знакомился с их творчеством, вступал с ними в своеобразный поэтический диалог. Внимание ненецкого автора привлекла импровизация Шервина Битсуна, пишущего на языке навахо. Его акустический перформанс вызвал мгновенный творческий отклик Вэллы:

$$
\begin{aligned}
& \text { to' } \\
& \text { to', } \\
& \text { to' }
\end{aligned}
$$


to'
to'
to'
to'
ви'
ви'
ви'
ви'
ви'
ви'
ви'

[Америка Юрия Вэллы]

В этих полуслучайных сонорных играх, экспериментах отражены и генетическая связанность миноритарных языков со звуковым миром природы, мифологическая, заклинательная функциональность слова, слога, символика чисел. Индейские поэты обращаются к тем же кодам художественности [Вэлла, 2011].

Вэлла - поэт, живший и писавший наедине со всеми. Невзирая на регулярные апелляции к коллективному (осознанному коллективному-родовому началу, неосознанному советскому), он был абсолютным раненым одиночеством северным индивидуалистом. Отсюда - очень развитое чувство ответственности, вдохновляющее и разрушительное одновременно.

Творчество Юрия Вэллы, на наш взгляд, занимает особое место в системе межлитературной общности народов России. С одной стороны, оно отражает отдельные закономерности развития национальных литератур на рубеже XX-XXI вв. (резкое усиление художественных позиций русского языка в этногуманитарной среде, наличие урбанистического мотивно-образного кластера, актуализированность экологической тематики, репрезентация социальных нарративов, высокий уровень этнографичности письма и др.). С другой - стихи Вэллы демонстрируют одну из возможных моделей движения поэтических традиций народов России в ближайшем будущем (увеличение значимости верлибра, повышенное внимание к этнолингвистическому «орнаментированию» текстов, расширение изобразительной составляющей в структуре книги, сосуществование под одной обложкой разных языков).

Некоторая наивность поэтической картины мира Юрия Вэллы, - по-видимому, осознанная художественная стратегия, воздействующая на реципиента и повышающая степень драматичности восприятия текстов. В некотором смысле Ю. Вэлла оэт-артист, понимающий, чего от него ждут читатели и критики, знающий, на какие «кнопки» словесности нужно нажимать. Традиционная культура, этноментальные особенности коммуникации лирических субъектов «погружены» в сложный синтетический дискурс современного верлибра. Вэлла - поэт взаимодействия, взаимоналожения различных культурных форм, разных семиотических систем. Очевидно, что творчество Юрия Вэллы - один из редких художественно-эстетических прорывов «миноритарной» литературы. 


\section{Литература}

Америка Юрия Вэллы (Дым Ю.). [https://www.proza.ru/]

Арзамазов А.А. Белые крики в черной тишине: этнопоэтический мир Юрия Вэллы // Эскизы: варианты, интертексты, стратегии, тактики, семиосферы, стиходвижение. Ижевск: Изд-во «Инвожо», 2005. C.89-93.

Вэлла Ю. Белые крики: книга о вечном. Сургут: Северный дом, 1996. - 166 с.

Вэлла Ю. Вести из стойбища. Радужный: Радужинская городская типография, 1991. -48 с.

Вэлла Ю. Земля любви: диалоги. Ханты-Мансийск: Принт-Класс, 2011. - 208 с.

Вэлла Ю. О реке, о любви и не только...: [стихи]. - Нижневартовск: Издательство Нижневартовского гуманитарного университета, 2013. - 48 с.

Вэлла Ю. Поговори со мной: книга для ненецкого студента и для того, кто хотел бы послушать ненецкую душу. Санкт-Петербург: Миралл, 2007. - 151 с.

Вэлла Ю. Река Аган со притоками. Опыт топонимического словаря. Бассейн реки Аган. Ханты-Мансийск: Информ.-издат. центр Югор. гос. ун-та, 2010. Ч. 1. - 147 с.

Вэлла Ю. Река Аган со притоками. Опыт топонимического словаря. Бассейн реки Аган. Ханты-Мансийск: Доминус, 2012а. Ч. 2. - 187 с.

Вэлла Ю. Река Аган со притоками. Опыт топонимического словаря. Бассейн реки Аган. Ханты-Мансийск: Юграфика, 2012б. Ч. 3. - 151 с.

Вэлла Ю. Триптихи = Няхаловш $=$ Triptyques. Ханты-Мансийск, 2001. -168 c.

Вэлла Ю., Юргенсон Т. Охота на лебедей: Диалог. Ханты-Мансийск: Полиграфист, 2001. - 10 с.

Жулева А.С. Юрий Вэлла: литератор, просветитель, оленевод // Вопросы истории и культуры северных стран и территорий. 2017, № 3 (35). - С.18-27.

Лагунова О.К. Поэтика книги Ю.К. Вэллы «Белые крики» // Вестник Тюменского государственного университета. 2003, № 4. - С.45-61.

Лагунова O.K. Феномен творчества русскоязычных писателей ненцев и хантов последней трети XX века (Е. Айпин, Ю. Вэлла, А. Неркаги): монография. Тюмень: Изд-во Тюменского гос. ун-та, 2007. $-258 \mathrm{c}$.

Новикова Н.И. Модель многокультурности Юрия Вэллы // Вестник угроведения. 2018, № 2, Т. 8. C.376-384.

Сподина В.И. Представление о пространстве в традиционном мировоззрении лесных ненцев. Новосибирск: Изд. Центр «Агро»: Изд. Группа «Солярис»: «ЦЭРИС», 2001. - 124 с.

Тулуз Эва. Две ветви одного дерева. Перевод с французского Марии Ерёменко // Мир Севера. 2000, № 5. - C.70-73.

\section{References}

Amerika Iuriya Velly (Dym Yu.) [Yuri Vella's America (Dym Y.)]. [https://www.proza.ru] Arzamazov A. A. Belye kriki v chernoi tishine: etnopoeticheskii mir Yuriya Velly [White screams in black silence: ethnopoetic world of Yuri Vella]. Eskizy: varianty, interteksty, strategii, taktiki, semiosfery, stikhodvizhenie [Sketches: options, intertexts, strategies, tactics, semiosphere, and poetry movement]. Izhevsk, Invozho, 2005. - pp. 89-93.

Vella Yu. Belye kriki: Kniga o vechnom [White screams: A book about the eternal]. Surgut, Severnyi dom, 1996. $-168 \mathrm{p}$.

Vella Yu. Vesti iz stoibishcha [News from the nomad camp]. Raduzhny, Raduzhinskaya gorodskaya tipografiya, 1991. $-48 \mathrm{p}$.

Vella Yu. Zemlya lyubvi: Dialogi [Land of love: Dialogues]. Khanty-Mansiysk, Print-Klass, 2011. - 208 p.

Vella Yu. O reke, o lyubvi i ne tol'ko...: stikhi [About the river, about love and not only ...: poems]. Nizhnevartovsk, Izdatel'stvo Nizhnevartovskogo gumanitarnogo universiteta, 2013. - 48 p.

Vella Yu. Pogovori so mnoi: kniga dlya nenetskogo studenta i dlya togo, kto khotel by poslushat'nenetskuyu dushu [Talk to me: a book for a Nenets student and for one who would like to listen to the Nenets soul]. St. Petersburg, Mirall, 2007. - 152 p.

Vella Yu. Reka Agan so pritokami. Opyt toponimicheskogo slovarya. Bassein reki Agan [Agan River with tributaries. Toponymic dictionary experience. Agan river basin]. Khanty-Mansiysk, Informatsionnoizdatel'skii tsentr Yugorskogo gosudarstvennogo universiteta, 2010. Part 1. - 146 p. 
Vella Yu. Reka Agan so pritokami. Opyt toponimicheskogo slovarya. Bassein reki Agan [Agan River with tributaries. Toponymic dictionary experience. Agan river basin]. Khanty-Mansiysk, Dominus, 2012. Part 2. $-186 \mathrm{p}$.

Vella Yu. Reka Agan so pritokami. Opyt toponimicheskogo slovaria. Bassein reki Agan [Agan River with tributaries. Toponymic dictionary experience. Agan river basin]. Khanty-Mansiysk, Yugrafika, 2012. Part 3. $-150 \mathrm{p}$.

Vella Yu. Triptikhi [Triptychs]. Khanty-Mansiysk, Poligrafist, 2001. - 168 p.

Vella Yu., Iurgenson T. Okhota na lebedei: Dialog [Swan hunting: Dialogues]. Khanty-Mansiisk, Poligrafist, 2001. $-10 \mathrm{p}$.

Zhuleva A. S. Yurii Vella: literator, prosvetitel', olenevod [Yuri Vella: writer, enlightener, and reindeer herder]. Voprosy istorii i kul'tury severnykh stran i territorii [Historical and cultural problems of northern countries and regions]. Syktyvkar, 2017, № 3 (35). - pp. 18-27.

Lagunova O. K. Poetika knigi Yu.K. Velly "Belye kriki" [Poetics of the book by Y.C. Vella "White screams"]. Vestnik Tyumenskogo gosudarstvennogo universiteta [Bulletin of Tyumen State University]. Tyumen, 2003, No 4. - pp. 45-61.

Lagunova O. K. Fenomen tvorchestva russkoyazychnykh pisatelei nentsev $i$ khantov poslednei treti XX veka (E. Aipin, Yu. Vella, A. Nerkagi) [The phenomenon of Russophone Nenets and Khanty writers of the last third of the 20th century (E. Aipin, J. Vella, A. Nerkagi)]. Tyumen, Izdatel'stvo Tyumenskogo gosudarstvennogo universiteta, 2007. $-258 \mathrm{p}$.

Novikova N. I. Model' mnogokul'turnosti Yuriia Velly [The multicultural model of Yuri Vella]. Vestnik ugrovedeniya [Bulletin of Ugric studies]. Khanty-Mansiysk, 2018, No 2. - pp. 376-384.

Spodina V. I. Predstavlenie o prostranstve v traditsionnom mirovozzrenii lesnykh nentsev [The idea of space in the traditional worldview of the forest Nenets]. Novosibirsk, Izdatel'skii tsentr "Agro", Izdatel'skaya gruppa "Solyaris", "TsERIS", 2001. - 124 p.

Tuluz E. Dve vetvi odnogo dereva [Two branches of the same tree], transl. from French by Maria Eremenko. Mir Severa [World of the North]. Moscow, 2000, No 5. - pp. 70-73. 